\title{
PENGARUH AMBIGUITAS PERAN DAN KONFLIK PERAN TERHADAP KREATIVITAS KARYAWAN
}

\author{
Petrus Hasiholan Tamba \\ Bandar Lampung, Lampung \\ petrustamba999@gmail.com
}

\author{
Ribhan $^{a}$, Keumala Hayati ${ }^{\text {b }}$, Dina Safitric \\ Jurusan Manajemen Fakultas Ekonomi dan Bisnis Universitas Lampung \\ ribhan@feb.unila.ac.id ${ }^{a}$,keumala.hayati@feb.unila.ac.id ${ }^{b \precsim}$,jodiesafitri@gmail.com ${ }^{c}$
}

\begin{abstract}
ABSTRAK
Tujuan dari penelitian ini adalah untuk mengetahui pengaruh dari ambiguitas peran dan konflik peran terhadap kreativitas karyawan. Penelitian ini menggunakan metode kausal dengan menggunakan data primer dari penyebaran kuesioner. Sampel penelitian adalah 126 responden alumni Fakultas Ekonomi dan Bisnis Universitas Lampung lulusan tahun 2015 sampai 2017 dan sudah bekerja. Data diolah dengan menggunakan metode regresi berganda. Hasil analisis menunjukkan bahwa ambiguitas peran memiliki pengaruh positif dan signifikan sebesar $44 \%$ terhadap kreativitas karyawan. Hasil lain dari penelitian ini menunjukkan bahwa konflik peran memiliki dampak positif sebesar 19\% terhadap kreativitas karyawan.
\end{abstract}

Kata Kunci: Ambiguitas Peran, Konflik Peran, Kreativitas Karyawan

\section{ABSTRACT}

This research aims to determine the influence of role ambiguity and role conflict on employee creativity. This research used the causal method by collecting primary data obtained through distributing questionnaires. Samples are 126 respondents of Faculty Economics and Business University Lampung alumnae who graduated 2015-2017. Data processed using multiple regression method. Result analysis shows that role ambiguity has a positive and significant influence on employee creativity with a value of 44\%. Another result of this research shows that role conflict positively influences employee creativity with a value of $19 \%$.

Keywords:Role Ambiguity, Role Conflict, Employee Creativity

\section{PENDAHULUAN}

Organisasi yang hebat adalah organisasi yang bisa mengelola sumber daya manusia mereka untuk bekerja serius dan dapat menjalankan bisnis organisasi seperti yang direncanakan untuk mencapai tujuan dan sasaran. Karyawan adalah aset yang paling banyak dan berharga dalam suatu organisasi, karena mereka bertindak sebagai eksekutor yang menjalankan seluruh tugas dan tanggung jawab dalam organisasi, ini menjadi alasan mengapa diperlukan manajemen sumber daya manusia yang tepat, mengelola karyawan serta membimbing mereka untuk melakukan yang terbaik untuk mencapai tujuan dan sasaran perusahaan menjadi masalah utama bagi manajer untuk mencari tahu cara paling efektif dan efisien, mengelola karyawan dengan baik merupaka hal yang sangat penting 
karena mengelola karyawan tidak semudah memberi tahu individu apa yang harus dilakukan dan membuat individu melakukan hal-hal berdasarkan perintah manajer yang perlu dilakukan secara sistematis.

Organisasi yang hebat tidak akan ada jika tidak memiliki kesamaan visi dan misi antara manajer dengan karyawan. Manajer membutuhkan karyawan dengan kemampuan yang menunjang keberhasilan organisasi di masa depan, salah satu kemampuan itu adalah kreativitas. Kreativitas menciptakan sesuatu yang bernilai, produk baru yang berguna, layanan, ide, prosedur, atau proses individu dalam bekerja di suatu organisasi yang kompleks. Manajemen harus menetapkan tujuan organisasi yang jelas untuk mencapai kreativitas yang maksimal, dengan cara memberikan kejelasan peran dan deskripsi pekerjaan yang tepat untuk setiap individu supaya membantu petinggi organisasi untuk menyelesaikan suatu masalah yang membutuhkan pemikiran kreatif.

Faktor lingkungan kerja dapat meningkatkan atau mengurangi motivasi intrinsik karyawan sehingga dapat meningkatkan atau mengurangi tingkat kreativitas, misalnya tekanan waktu dapat menguntungkan atau membahayakan kreativitas karyawan, kemudian seperti stres peran yang berdampak pada produktivitas karyawan. Pemahaman bagaimana stres peran dapat mempengaruhi tingkat kreativitas karyawan, karena ambiguitas peran dan konflik peran adalah komponen utama dari stres peran (Amabile et al. (1996).

Ambiguitas peran mencerminkan kepastian tentang tugas, wewenang, alokasi waktu, dan hubungan dengan orang lain ini merupakan kejelasan atau keberadaan panduan, arahan, kebijakan; dan kemampuan untuk prediksi sanksi sebagai hasil dari perilaku. Ambiguitas peran mengacu pada kurangnya spesifisitas dan prediktabilitas untuk pekerjaan atau peran karyawan dalam fungsi dan tanggung jawab. Mumford (2000) menegaskan bahwa tujuan adalah mekanisme pengarahan informasi. Tujuan adalah faktor penting dalam kreativitas, karena individu sering mengalami perasaan ambigu yang dapat menyebabkan stres. Amabile (1983) dan Backer (1992) menunjukkan bahwa mengelola stres, ambiguitas, dan konflik sangat penting untuk memastikan pemikiran kreatif dan kebutuhan motivasi intrinsik individu.

Konflik peran dihasilkan dari dua atau lebih banyak permintaan yang tidak kompatibel yang terkait dengan masalah pekerjaan. Konflik peran sebagai ukuran dari ketidak sesuaian atau ketidak cocokan dalam persyaratan peran, dimana kompatibilitas dinilai relatif terhadap seperangkat standar atau kondisi yang menimpa kinerja peran, misalnya seorang karyawan yang harus memainkan dua atau lebih peran memungkinkan menemukan bahwa tuntutan peran tidak kompatibel. Konflik peran dapat dijelaskan sebagai konflik internal yang terjadi pada diri seseorang, dan akan terjadi ketika individu menghadapi suatu ketidak pastian pekerjaan yang dia harapkan untuk melakukannya, apabila berbagai permintaan pekerjaan saling bertentangan, atau bila individu diharapkan untuk melakukan lebih dari kemampuannya. Konflik peran dipandang sebagai ketidak sesuaian antara harapan yang dikomunikasikan dengan peran yang dijalankan.

Kreativitas menjadi faktor penting di dalam organisasi, terutama pada kondisi dimana organisasi menghadapi lingkungan yang kompetitif. Inisiatif dan implementasi dari ide kreatif meningkatkan kemampuan organisasi untuk merespon peluang yang ada. Peningkatan kinerja kreatif dari pekerja merupakan suatu keharusan jika organisasi ingin mencapai keunggulan yang kompetitif (Amabile, 1988). Kreativitas merupakan hasil ide baru yang berpotensi dan berharga mengenai produk, pelayanan, metode, dan proses administratif (Zhou dan George (2001).

Universitas Lampung merupakan lembaga pendidikan yang menghasilkan output berupa lulusan-lulusan terdidik dan terampil dan terus mengupayakan peningkatan daya saing lulusan agar mampu berkompetisi di pasar kerja maupun menghasilkan lulusan yang mampu menciptakan lapangan pekerjaan. Fakultas Ekonomi dan Bisnis merupakan fakultas 
pertama yang ada di Unila dan memiliki visi dan misi yang sejalan dengan visi jangka panjang Unila yaitu menjadi perguruan tinggi sepuluh terbaik di Indonesia, upaya untuk mewujudkan visi jangka panjang ini salah satu nya dengan menghasilkan alumni-alumni yang mampu berkompetisi di pasar kerja, dalam hal ini Fakultas Ekonomi dan Bisnis pada tahun 2015-2017 telah meluluskan alumni yang terdiri dari mahasiswa angkatan 2009, 2010, 2011, 2012, dan 2013 program studi sarjana/S1 dan Diploma III, untuk mencari tahu apakah lulusan ini mampu berkompetisi di pasar kerja maka peneliti berusaha mencari tahu fenomena ambiguitas peran dan konflik peran yang terjadi di dalam organisasi dari sudut pandang alumni yang bekerja di alam organisasi yang berbeda dan kepribadian individu yang berbeda untuk mengetahui pegaruh terbentuknya ide kreatif. Penelitian ini ingin menguji apakah variabel ambiguitas peran dan konflik peran mempengaruhi kreativitas alumni sehingga organisasi dapat menghindari masalah di masa depan. Penelitian ini akan berfokus pada pengaruh ambiguitas peran dan konflik peran pada kreativitas karyawan pada alumni yang berstatus karyawan.

\section{KAJIAN LITERATUR Ambiguitas Peran}

Ambiguitas merupakan cermin kepastian tentang tugas, wewenang, alokasi waktu, dan hubungan dengan orang lain yaitu kejelasan atau keberadaan panduan, arahan, kebijakan; dan kemampuan untuk memprediksi sanksi sebagai hasil dari perilaku (Rizzo et al, 1970). Ambiguitas peran adalah "tidak adanya informasi umpan balik hasil evaluasi pengawas tentang hasil kerja seseorang, tentang peluang-peluang kenaikan karir, cakupan tanggung jawab, dan pengharapan-pengharapan si penyampai peran" (Katz dan Kahn, 1978).

Ambiguitas peran dapat muncul disebabkan kurangnya informasi atau karena tidak adanya informasi sama sekali atau informasinya tidak disampaikan kepada individu mengenai pekerjaannya. Ambiguitas peran juga disebabkan karena meningkatknya tuntutan pekerjaan, tekanan waktu dalam penyelesaian tugas, dan ketidak pastian pengawasan oleh atasan yang mengakibatkan karyawan harus menebak dan memprediksikan sendiri setiap tindakannya. Ambiguitas peran tersebut dapat dikurangi antara lain dengan (1) memperkirakan hasil atau tanggapan yang timbul dari suatu tindakan perilaku, (2) adanya kejelasan tentang syarat-syarat perilaku akan dapat membantu menjadi pedoman perilaku (Rizzo et al., 1970). Ambiguitas peran adalah kebalikan dari kejelasan peran. Kejelasan peran difasilitasi oleh hubungan supervisor-bawahan yang efektif dan persepsi kepuasan dengan kualitas kerja tim (Firth-Cozen, 2001).

Pada penelitian sebelumnya menurut Amabile (1988) dapat diakui secara luas, bahwa kreativitas sangat penting untuk keunggulan kompetitif dan kelangsungan hidup organisasi. Para peneliti ini mengidentifikasi hal itu ke dalam faktor lingkungan kerja yang dapat meningkatkan atau mengurangi motivasi intrinsik karyawan dalam upaya meningkatkan tingkat kreativitas individu. Konsep ambiguitas peran yang diterima secara umum menurut Breaugh dan Colihan (2004) adalah bahwa ambiguitas peran terjadi ketika individu tidak memiliki definisi yang jelas tentang harapan peran mereka. Ambiguitas peran juga dapat didefinisikan sebagai kekurangan persyaratan atau metode untuk menyelesaikan tugas pekerjaan mereka. Rizzo, House, \& Lirtzman (1970) karyawan dapat mengalami ambiguitas peran karena berbagai alasan. Para karyawan sering memasuki situasi di mana tidak ada kemungkinan untuk informasi yang lengkap, oleh karena itu sulit untuk menerima instruksi yang jelas atau menerapkan pelatihan yang diterima dalam situasi tertentu. kurangnya informasi ini dapat meningkatkan ketidak pastian terkait harapan yang terkait dengan peran. Gupta dan Jenkins (1985) dengan tidak adanya definisi yang jelas seperti disebutkan di atas, untuk tujuan tersebut maka ambiguitas peran akan didefinisikan sebagai ambiguitas pada 
pekerjaan yang terjadi karena kurangnya peran yang jelas, harapan, persyaratan, metode, dan informasi dalam pengalaman situasional.

Teori lain menyatakan peran ambiguitas dapat didefinisikan sebagai kurangnya kekhususan dan prediktabilitas untuk pekerjaan atau peran fungsi karyawan dan tanggung jawab (Kahn et al., (1964). Ambiguitas peran bias hasil dari deskripsi pekerjaan yang buruk, instruksi tidak jelas dari pengawas, atau isyarat yang tidak jelas dari rekan kerja. Hasil ambiguitas peran adalah ketidaktahuan pada pekerjaan dan dengan demikian menjadi sumber signifikan hasil yang tidak diinginkan seperti stress. Griffin dan Moordhead (2009) informasi terkait peran yang tidak jelas dapat menyebabkan ambiguitas. Tujuan merupakan faktor penting dalam kreativitas karena mereka sering ambigu, dan ambiguitas dapat menyebabkan tekanan, selain itu, Tang dan Chang (2010) menyarankan karyawan yang bingung dengan tujuan lain yang ada untuk mencoba mengatasi ketegangan atau mengurangi ketegangan dengan meninggalkan inisiatif kreatif, oleh karena itu manajemen harus menetapkan tujuan organisasi yang jelas untuk mencapai tingkat kreativitas yang tinggi.

Indikator-indikator dari ambiguitas peran yang dikembangkan oleh Rizzo, House dan Lirtzman sebagai berikut:

1) Merasa pasti dengan seberapa besar wewenang yang dimiliki dan tidak mempunyai rencana yang jelas untuk pekejaan.

2) Mempunyai tujuan yang tidak jelas untuk pekerjaan dan mengetahui bahwa perlunya membagi waktu dengan tepat.

3) Mengetahui apa yang menjadi tanggung jawab dan penjelasan tentang apa yang harus dikerjakan adalah tidak jelas.

4) Mengetahui cakupan dari pekerjaan dan tidak jelas bagaimana kinerja di evaluasi.

Ambiguitas peran dan konflik peran juga terjadi di antara variabel stres peran yang paling banyak dipelajari dan menempatkan ambiguitas peran dan konflik peran mempengaruhi kreativitas karyawan. Ambiguitas peran dan kreativitas menurut teori ambiguitas peran mengacu pada kurangnya spesifisitas dan prediktabilitas untuk pekerjaan atau peran karyawan berupa fungsi dan tanggung jawab (Kahn et al., 1964).

\section{Konflik Peran}

Konflik peran sebagai ukuran dari ketidak sesuaian atau ketidak cocokan dalam persyaratan peran, dimaa kompatibilitas dinilai relatif terhadap seperangkat standar atau kondisi yang menimpa kinerja peran, misalnya seorang karyawan yang harus memainkan dua atau lebih peran memungkinkan menemukan bahwa tuntutan peran tidak kompatibel (Rizzo et al., 1970). Konflik peran lebih intens dalam pekerjaan di mana pemikiran lebih abstrak dan pengambilan keputusan diperlukan. Konflik peran muncul sebagai akibat dari harapan peran dari satu pengirim yang bertentangan dengan harapan satu atau lebih banyak pengirim peran (Menon dan Aknilesh, 1994). Konflik peran juga telah ditentukan sejauh mana seseorang mengalami tekanan dalam satu peran yang tidak sesuai dengan tekanan itu muncul dalam peran lain. Rizzo, House dan Lirtzman (1970) konflik peran juga dapat didefinisikan sebagai ketidakcocokan persyaratan dan harapan dari peran. Rizzo et. al., (1970) mendefinisikan konflik peran dikaitkan dengan dimensi-dimensi kesesuaian - ketidak sesuaian atau kecocokan - ketidak cocokan terhadap persyaratan suatu peran, sebelumnya penelitian Kahn et al., (1964) menyatakan bahwa tekanan dalam pekerjaan muncul karena adanya dua kondisi yang sering dihadapi, yakni ambiguitas peran dan konflik peran. Persoalan bisa berasal dari individu sebagai aktor, bisa juga berasal dari mitra yang berkaitan dengan aktifitas menjalankan peran. Konflik peran terjadi manakala seseorang dengan tuntutan yang bertentangan melakukan peran yang berbeda. 
Indikator-indikator dari konflik peran yang dikembangkan oleh Rizzo, House dan Lirtzman sebagai berikut:

1) Melakukan suatu pekerjaan dengan cara yang berbeda-beda dan menerima penugasan tanpa sumber daya manusia yang cukup untuk menyelesaikannya.

2) Mengesampingkan aturan agar dapat menyelesaikan tugas dan menerima permintaan dua pihak atau lebih yang tidak sesuai satu sama lain.

3) Melakukan pekerjaan yang cendrung diterima oleh satu pihak tetapi tidak diterima oleh pihak lain dan melakukan kegiatan yang sebenarnya tidak perlu.

4) Bekerja di bawah arahan yang tidak pasti dan perintah yang tidak jelas.

Konflik peran dan kreativitas menurut teori konflik peran dihasilkan dari dua atau lebih banyak permintaan yang tidak kompatibel yang terkait dengan masalah pekerjaan (Kahn et al., 1964). Menurut Farr dan Ford (1990) stres menghasilkan pola perilaku rutin dan umumnya mengganggu respons kreatif. Jex (1998) mencatat stress dan tekanan menghambat aspek motivasi kinerja, seperti upaya nyata atau melampaui tanggung jawab pekerjaan rutin. Taggar (2002) menunjukkan bahwa tim mengalami kesulitan dalam menetapkan tugas dan perannya namun tim atau anggota secara tidak langsung dapat mengalihkan perhatian individu dan langsung dari kemampuan tim untuk tampil kreatif, meskipun berpotensi negatif bukti sebaliknya menunjukkan bahwa konflik peran mungkin meningkatkan kreativitas, selain itu ketegangan sering dianggap respon negatif emosional terhadap stres yang pada akhirnya bisa mengarah pada dampak negatif (Rothbard, 2001).

Penelitian lain menunjukkan bahwa pengaruh negatif mungkin meningkatkan kreativitas sebagai contoh, Ludwig (1992) menemukan depresi dan tingkat pencapaian kreatif sedikit, tetapi secara signifikan berkorelasi satu sama lain. Beberapa studi mengadopsi pandangan positif terhadap konflik peran, misalnya ketika individu terlibat dalam berbagai peran, itu mungkin menciptakan pengaruh positif (Lenaghan dan Sengupta, 2007). Beberapa peneliti menyarankan bahwa pengaruh positif mengarah pada variasi kognitif yang merangsang kreativitas, misalnya Isen (1999) menyatakan bahwa melalui proses kognitif, pengaruh positif meningkatkan kreativitas lalu peneliti lain menegaskan konflik peran dapat mengekspos individu ke perspektif yang berbeda dan membuat mereka lebih fleksibel dan memperluas sumber informasinya (Jones, 1993), singkatnya konflik peran tampaknya dapat meningkatkan atau mengurangi kreativitas.

\section{Kreativitas}

Kreativitas umumnya didefinisikan sebagai produk ide-ide yang baru dan bermanfaat, menurut Shalley et al., (2004) penilaian kreativitas diri disebabkan karena karyawan sendiri lebih cenderung menyadari kehalusan saran mereka yang membuat ide-ide mereka kreatif. Dibeberapa peneliti lain berpendapat bahwa kreativitas dimulai pada tahap "kesadaran" dimana individu mengenali peluang untuk menjadi kreatif dan merumuskan inovasi potensial. Menurut Ong et al., (2003) karyawan mungkin lebih mampu dari pada supervisor karena untuk menilai sejauh mana ide-ide baru pada dasarnya inkremental konteks kerja, sering diperdebatkan bahwa menjadi kreatif adalah jenis perilaku bebas yang tujuannya adalah untuk menguntungkan organisasi berdasarkan pada studi oleh Axtell et al., (2000) karyawan mungkin berada dalam posisi terbaik untuk intensitas atau frekuensi perilaku yang dimaksudkan.

Janssen (2000) menyatakan bahwa rekan kerja mungkin tidak memperhatikan kontribusi kreatif karyawan lainya kecuali karyawan tersebut secara bersamaan terlibat dalam tujuan untuk mendapatkan persetujuan atasan dan rekan kerja. Ide-ide baru mungkin mengacaukan cara atau menekankan hubungan interpersonal yang ada, akibatnya karyawan 
mungkin merasa enggan untuk mempresentasikan idenya untuk atasan dan teman sebaya terutama jika mereka menganggap atasan dan teman sebaya mungkin tidak memberikan antusiasme, oleh karena itu karyawan dapat mengajukan saran kepada kolega atau anggota senior organisasi lainnya untuk mendapatkan validasi dan dukungan untuk ide-ide mereka. Kreativitas menjadi faktor penting di dalam organisasi, terutama pada kondisi dimana organisasi menghadapi lingkungan yang kompetitif. Inisiatif dan implementasi dari ide kreatif meningkatkan kemampuan organisasi untuk merespon peluang yang ada. Peningkatan kinerja kreatif dari pekerja merupakan suatu keharusan jika organisasi ingin mencapai keunggulan kompetitifnya (Amabile, 1988). Kreativitas adalah menghasilkan ide baru yang berpotensi dan berharga mengenai produk, pelayanan, metode, dan proses administratif (Zhou dan George, 2001). Woodman, Sawyer dan Griffin (1993) mendefinisikan kreativitas sebagai menciptakan sesuatu yang bernilai, produk baru yang berguna, layanan, ide, prosedur, atau proses oleh individu yang bekerja dalam organisasi sosial yang kompleks. Oldham dan Cummings (1996) mendefinisikan kinerja kreatif sebagai produk, ide, atau prosedur yang memenuhi dua kondisi yaitu (1) baru atau orisinil dan (2) berguna bagi organisasi.

Studi kreativitas merujuk pada kreativitas individu atau sosial. Kreativitas pribadi mengacu pada menciptakan sesuatu yang baru sehubungan dengan orang yang menciptakan produk. Kreativitas sosial mengacu pada sesuatu yang bermanfaat terkait dengan lingkungan sosial atau budaya tempat diproduksi. Dalam kreativitas dua hal yang terpenting adalah keaslian dan kegunaan (Mayer, 1999). Feldman, (1999) kreativitas adalah konstruk dari multidimensi yang melibatkan proses kognitif dan sosial emosional, keluarga, klan, pendidikan formal dan informal, karakterisitik domain dan disiplin, konteks sosial-budaya, dan sejarah. Setiap orang adalah pencipta dengan berbagai tingkatan kreativitas. Dalam teori investasi tingkatan kreativitas memerlukan sumber daya setiap orang yang melibatkan enam sumber daya yang berbeda tetapi saling terkait, yaitu: kemampuan intelektual, pengetahuan, pola berpikir, kepribadian, motivasi, dan lingkungan (Zhang dan Sternberg, 2011).

Kreativitas adalah sarana ekspresi dan refleksi manusia di dunia sekitar kita, para psikolog menggunakan kreativitas untuk membantu anak-anak memulai dialog untuk mengatasi stres, dan mengeksplorasi berbagai aspek kepribadian mereka sendiri. Kreativitas juga dapat dipahami sebagai kekuatan yang memiliki kualitas untuk mengekspresikan diri dengan caranya sendiri. Anak-anak secara alami adalah kreatif mereka melihat dunia melalui mata baru dan kemudian melihat apa yang mereka lihat dengan cara yang orisinal, jadi kreativitas adalah karakteristik manusia yang terbaik dan menganggapnya sebagai proses, membutuhkan campuran bahan, termasuk ciri-ciri kepribadian, kemampuan dan keterampilan.

Aspek dalam kreativitas individu yaitu "expertise, creative thinking skill, and intrinsic task motivation," yang masing-masing sangat penting untuk kreativitas dan ketiga aspek tersebut saling berinteraksi. Aspek keahlian merupakan pondasi untuk pekerjaan kreatif. Keahlian dapat dipandang sebagai himpunan alur kognitif yang dapat diikuti untuk memecahkan masalah tertentu atau melakukan tugas yang diberikan. Aspek berfikir kreatif memberikan ekstra dari kinerja kreatif dengan asumsi bahwa seseorang memiliki beberapa insentif untuk melakukan suatu kegiatan, sehingga kinerja secara teknis baik jika keahlian diperlukan. Aspek motivasi tugas intrinsik, motivasi dapat berupa intrinsik (didorong oleh minat mendalam keterlibatan dalam pekerjaan, oleh rasa ingin tahu, kenikmatan, atau rasa tantangan pribadi). Pengembangan seseorang dari keahlian dan praktek keterampilan berpikir kreatif dapat dipengaruhi sampai batas tertentu oleh lingkungan sosial. Pengaruh terkuat dan paling langsung dari lingkungan adalah motivasi. Seseorang dimulai dengan tingkat motivasi intrinsik kemudian tergantung pada kenikmatan dalam pekerjaannya (Amabile, 1997). 


\section{Kerangka Pemikiran}

Kerangka penelitian ini dapat dilihat pada Gambar 1. Gambar 1 menunjukkan kerangka pemikiran guna menggambarkan hubungan antara variabel independen dengan variabel dependen. Berikut adalah kerangka pemikiran dari penelitian ini :

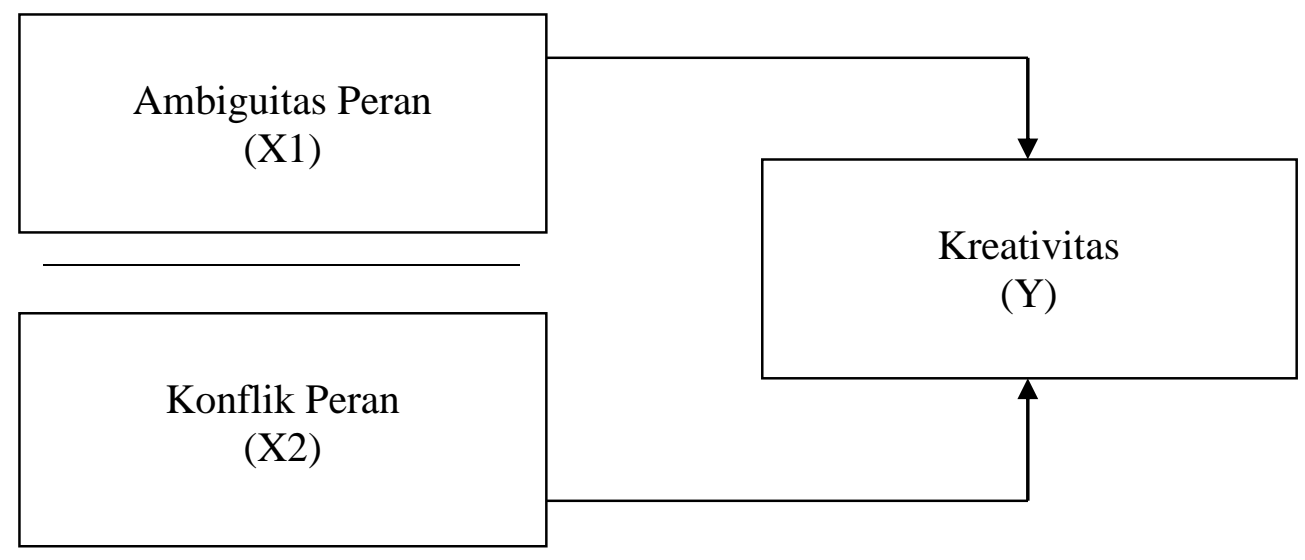

Gambar 1 Kerangka Pemikiran

\section{Hipotesis}

Berdasarkan kajian literatur dan kerangka pemikiran yang telah diuraikan maka dapat ditarik hipotesis sebagai berikut:

\section{Pengaruh Ambiguitas Peran Terhadap Kreativitas}

Amabile $(1988,1996)$ sebagai kerangka umum bahwa faktor mental atau sosial dapat meningkatkan atau mengurangi kreativitas karyawan. Model ini benar-benar ditinjau bagaimana kognitif, kepribadian, pengaruh motivasi, dan sosial berdampak pada kreativitas, meskipun tidak secara khusus mendefinisikan lingkungan tertentu menjadi faktornya, model ini berusaha menjelaskan mengapa karyawan sangat penting bekerja dengan kreativitas. Model Amabile memandang tekanan beban kerja sebagai faktor lingkungan kerja mempengaruhi kreativitas, apalagi penelitian lain seperti Amabile (1983) dan Backer (1992) menunjukkan bahwa mengelola stres, ambiguitas, dan konflik sangat penting untuk memastikan pemikiran kreatif dan kebutuhan motivasi intrinsik.

Ambiguitas peran dan konflik peran juga terjadi di antara variabel stres peran yang paling banyak dipelajari dan menempatkan ambiguitas peran dan konflik peran mempengaruhi kreativitas karyawan. Ambiguitas peran dan kreativitas menurut teori peran, ambiguitas peran mengacu pada kurangnya spesifisitas dan prediktabilitas untuk pekerjaan atau peran karyawan berupa fungsi dan tanggung jawab (Kahn et al., 1964; Beehr,1976). Informasi terkait peran yang tidak jelas dapat menyebabkan peran kemenduaan persis bagaimanapengaruh harapan atau tujuan peran kreativitas telah menerima minat yang cukup besar. Mumford (2000) menegaskan bahwa tujuan adalah mekanisme pengarahan informasi, tujuan adalah faktor penting dalam kreativitas karena mereka sering ambigu dan ambiguitas dapat menyebabkan stress, selain itu Ford (1996) menyarankan agar karyawan yang bingung dengan mengatasi ketegangan atau untuk mengurangi ketegangan dapat meninggalkan inisiatif kreatif. Taggar (2002) menunjukkan bahwa tim mengalami kesulitan dalam menetapkan tugas, dan peran tim atau anggota individu, secara tidak langsung dapat mengalihkan perhatian individu untuk tampil kreatif di dalam sebuah tim, meskipun berpotensi dampak negatif dari konflik peran,bukti sebaliknya menunjukkan bahwa konflik peran mungkinhance kreativitas 
Amabile dan Gryskiewicz (1987), manajemen harus menetapkan tujuan organisasi yang jelas mencapai kreativitas yang tinggi. Sherman (1989) mendalilkan kejelasan peran adalah motivator positif, selain itu kejelasan peran juga terkait inovasi positif (Jansen dan Gaylen, 1994). Ini menyiratkan bahwa ambiguitas peran negatif dan signifikan mempengaruhi kreativitas karyawan, oleh karena itu peneliti menghipotesiskan sebagai berikut:

H1: Variabel ambiguitas peran (X1) berpengaruh positif terhadap kreativitas karyawan (Y).

\section{Pengaruh Konflik Peran Terhadap Kreativitas}

Konflik peran dan kreativitas menurut teori konflik peran dihasilkan dari dua atau lebih banyak permintaan yang tidak kompatibel yang terkait dengan masalah pekerjaan (Kahn et al., 1964; Katz dan Kahn, 1978). Menurut Farr dan Ford (1990) stres menghasilkan pola perilaku rutin dan umumnya mengganggu respons kreatif. Jex (1998) mencatat stress dan tekanan menghambat aspek motivasi kinerja, seperti upaya nyata atau melampaui tanggung jawab pekerjaan rutin. Taggar (2002) menunjukkan bahwa tim mengalami kesulitan dalam menetapkan tugas dan perannya namun tim atau anggota secara tidak langsung dapat mengalihkan perhatian individu dan langsung dari kemampuan tim untuk tampil kreatif, meskipun berpotensi negatif dari konflik peran, bukti sebaliknya menunjukkan bahwa konflik peran mungkin meningkatkan kreativitas, selain itu ketegangan sering dianggap respon negatif emosional terhadap stres yang pada akhirnya bisa mengarah pada dampak negatif (Rothbard, 2001).

Penelitian menunjukkan bahwa pengaruh negatif mungkin meningkatkan kreativitas sebagai contoh, Ludwig (1992) menemukan depresi dan tingkat pencapaian kreatif sedikit, tetapi secara signifikan berkorelasi satu sama lain. Beberapa studi mengadopsi pandangan positif terhadap konflik peran, misalnya ketika individu terlibat dalam berbagai peran, itu mungkin menciptakan pengaruh positif (Lenaghan dan Sengupta,2007). Beberapa peneliti menyarankan bahwa pengaruh positif mengarah pada variasi kognitif yang merangsang kreativitas, misalnya Isen (1999) menyatakan bahwa melalui proses kognitif, pengaruh positif meningkatkan kreativitas lalu peneliti lain menegaskan konflik peran dapat mengekspos individu ke perspektif yang berbeda dan membuat mereka lebih fleksibel, dan memperluas sumber informasinya (Jones, 1993; Seiber, 1974), singkatnya konflik peran tampaknya dapat meningkatkan atau mengurangi kreativitas, oleh karena itu peneliti menghipotesiskan sebagai berikut:

H2: Variabel konflik peran (X2) berpengaruh positif terhadap kreativitas karyawan (Y).

\section{METODE PENELITIAN}

Variabel yang digunakan dalam penelitian ini adalah variabel bebas yaitu ambiguitas peran dan konflik peran kemudian variabel terikat yaitu kreativitas. Jenis penelitian ini adalah penelitian kausal, sedangkan tujuan dari penelitian ini adalah untuk menentukan hubungan antara dua variabel dengan variabel lain. Objek analisis penelitian ini adalah alumni Fakultas Ekonomi dan Bisnis Universitas Lampung yang lulus pada tahun 2015 sampai 2017 yang merupakan mahasiswa dan mahasiwi mulai dari angkatan 2009, 2010, 2011, 2012 dan 2013 program studi sarjana strata 1 dan diploma III yang sudah bekerja dan berstatus karyawan yang menjadi responden dari kuesioner. Sumber data yang akan digunakan dalam penelitian ini adalah data primer yang diperoleh melalu kuesioner menggunakan skala 1-5 Likert yang diberikan kepada responden yang merupakan seluruh sampel. Penelitian ini juga menggunakan data sekunder dari jurnal dan juga buku teks.

Populasi dari peneltian ini adalah alumni Fakultas Ekonomi dan Bisnis Universitas Lampung yang lulus pada tahun 2015 sampai 2017 program studi sarjana strata 1 dan diploma III yang sudah bekerja dan berstatus karyawan. Sampel terdiri dari subjek yang memiliki spesifikasi karakteristik dan memiliki kesempatan yang sama untuk dipilih sebagai 
sampel, oleh karena itu ini adalah penelitian terhadap sampel. Hair et. al., (1998) jumlah sampel minimal adalah lima kali dari jumlah butir pertanyaan yang terdapat dikuesioner. Jumlah sampel pada penelitian ini adalah 126 responden dan menurut Hair et al merekomendasikan sampel ideal 100-200 responden, dengan demikian jumlah sampel memadai untuk selajutnya dihitung.

Tahap analisis dalam penelitian ini dimulai dengan mengumpulkan dan mengolah data yang diperoleh dari kuesioner dengan memberikan bobot dari setiap pernyataan berdasarkan skala Likert, kemudian melakukan uji instrumen penelitian yang berguna untuk mengetahui validitas, reliabilitas dan normalitas data yang diperoleh dari tiap item kuesioner yang di isi responden dengan tujuan data tersebut dapat digunakan sebagai alat pembuktian hipotesis, setelah itu melakukan analisis kuantitatif menggunakan uji regresi berganda dan di deskripsikan dan akhirnya menunjukkan korelasi dan uji regresi kemudian terakhir dilakukan uji hipotesis mengguakan uji t, dalam praktiknya data diproses dengan bantuan komputer dan menggunakan software SPSS.

\section{HASIL DAN PEMBAHASAN \\ Pengujian Instrumen}

Penelitian ini memaparkan bahwa validitas suatu butir kuesioner dapat diketahui jika nilai KMO lebih besar atau sama dengan nol koma lima, bila terdapat nilai MSA yang kurang dari nol koma lima maka variabel dengan nilai MSA terkecil harus dikeluarkan dan begitu seterusnya sampai tidak ada lagi nilai MSA yang kurang dari nol koma lima. Hasil uji validitas yang menggunakan bantuan program statistik SPSS menunjukkan semua item pernyataan pada kuesioner yang mewakili item variabel dari ambiguitas peran (X1), konflik peran (X2) dan kreativitas (Y) dengan nilai $K-M-O M S A$ lebih besar atau sama dengan nol koma lima dan nilai $M S A$ lebih besar atau sama dengan nol koma enam dengan Sig dibawah atau setara nol koma lima sehingga dinyatakan valid dan dapat diproses untuk langkah selanjutnya.

Penelitian ini memaparkan bahwa penghitungan reliabilitas dilakukan dengan menggunakan teknik pengukuran Chronbach Alpha, hasil pengujian dapat dikatakan reliabel apabila Chronbach Aplha bernilai diatas nol koma enam. Hasil uji reliabilitas yang menggunakan bantuan program statistik SPSS menunjukkan item pernyataan pada kuesioner yang mewakili item variabel dari ambiguitas peran (X1), konflik peran (X2) dan kreativitas (Y) semua nilai Croanbach's Alpha diatas nol koma enam dan nilai Croanbach's Alpha if item Deleted tidak melebihi nilai Croanbach's Alpha, berdasarkan hasil tersebut dapat dinyatakan seluruh instrument kuesioner ini reliabel.

Uji normalitas bertujuan untuk menguji apakah dalam model regresi, data dalam penelitian mempunyai distribusi normal atau tidak. Pengujian ini dapat dilakukan dengan melihat profitabilitas dari Kolmogorov Smirnov Z statistik, jika profitabilitas Z statistik lebih kecil dari 0,05 maka nilai residiual dalam suatu regresi tidak terdistribusi secara normal. Hasil uji normalitas yang menggunakan bantuan program statistik SPSS menunjukkan item pernyataan pada kuesioner yang mewakili item variabel dari ambiguitas peran (X1), konflik peran (X2) dan kreativitas (Y) menunjukan nilai Kolmogorov-Smirnov Z serta nilai sig bernilai diatas nol koma nol lima, hal ini membuktikan bahwa keseluruhan data dalam penelitian berdistribusi normal. 


\section{Karakteristik Responden}

Hasil dari rekapitulasi karakteristik responden menunjukan perbandingan pada jenis kelamin responden dimana jumlah responden laki-laki adalah 42 dan 84 merupakan responden perempuan. Perbandingan pada usia responden menunjukan bahwa 64 responden berusia 25 tahun, 29 responden berusia 26 tahun, 24 responden berusia 27 tahun, lima responden berusia 28 tahun dan empat responden berusia 29 tahun. Perbandingan pada pendidikan terakhir responden menunjukan bahwa 20 responden berpendidikan Diploma III, 101 responden berpindidikan Sarjana strata I, dan lima responden berpindidikan Sarjana strata II.

\section{Analisis Regresi Linier Berganda}

Analisis kuantitatif dilakukan untuk mengetahui pengaruh ambiguitas peran dan konflik peran terhadap kreativitas dengan menggunakan regresi linier berganda. Hasil uji regresi linier berganda yang menggunakan bantuan program statistik SPSS menunjukkan bahwa nilai konstan adalah sebesar 18,503, nilai ambiguitas peran (X1) sebesar 0,447, dan konflik peran (X2) adalah sebesar 0,196, berdasarkan nilai-nilai tersebut maka persamaan regresi liner berganda adalah sebagai berikut:

$$
\begin{gathered}
Y=a+b_{1} X 1+b_{2} X 2 \\
Y=18,503+0,447 X 1+0,196 X 2
\end{gathered}
$$

Persamaan fungsi regresi serta hasil koefisien regresi tersebut mencerminkan bahwa dalam penelitian ini menunjukan setiap variabel ambiguitas peran dan konflik peran (X) memiliki pengaruh positif terhadap variabel kreativitas (Y).

\section{Uji Hipotesis (Analisis Uji t)}

Pengujian ini dimaksudkan untuk mengetahui apakah masing-masing variabel independen berpengaruh signifikan terhadap variabel dependen, dikatakan berpengaruh signifikan apabila sig < a $(0,05)$. Pengujian ini dilakukan dengan tingkat kepercayaan $95 \%$ dengan ketentuan sebagai berikut:

$>$ Jika thitung $>$ ttabel $(0,05)$, maka Ha diterima dan $\mathrm{H}_{0}$ ditolak.

$>$ Jika thitung $<$ tabel $(0,05)$. maka Ha ditolak dan $\mathrm{H}_{0}$ diterima.

Hasil analisis uji $\mathrm{t}$ yang menggunakan bantuan program statistik SPSS dan berdasarkan pada nilai ${ }^{t}$ tabel menunjukan bahwa variabel ambiguitas peran (X1) memiliki pengaruh positif dan signifikan terhadap variabel kreativitas (Y), sedangkan variabel konflik peran (X2) memiliki pengaruh positif da signifikan terhadap variabel kretivitas (Y). Melalui analisis regresi berganda yang dilakukan pada alumni Fakultas Ekonomi dan Bisnis Universitas Lampung status karyawan, hasil yang diperoleh adalah: (1) Ambiguitas peran (X1) memiliki pengaruh positif dan signifikan terhadap kreativitas karyawan (Y) dengan nilai $(0,447)$. (2) Konflik peran (X2) memiliki pengaruh positif dan signifikan terhadap kreativitas karyawan (Y) dengan nilai $(0,196)$.

Berdasarkan hasil penelitian di atas, dapat dismpulkan bahwa ada pengaruh yang signifikan antara ambiguitas peran dan kreativitas karyawan dan hasil penelitian lainnya bahwa ada pengaruh positif dan signifikan antara konflik peran dan kreativitas pada alumni Fakultas Ekonomi dan Bisnis Universitas Lampung stastus karyawan. Menurut Tang dan Chang (2010) kejelasan peran adalah motivasi positif bagi para petinggi organisasi dan karyawan, menurut penelitian ini petinggi organisasi cenderung menyelesaikan masalah dengan membutuhkan upaya dan inovasi tingkat tinggi untuk menyelesaikan sebuah proyek. 
Kejelasan peran merupakan salah satu dimensi ambiguitas peran yang mengacu pada seberapa jelas seperangkat kegiatan yang diharapkan dari seorang individu, tetapi ambiguitas peran merupakan situasi sebaliknya, ini menyiratkan bahwa ambiguitas peran negatif dan signifikan mempengaruhi kreativitas karyawan menurut penelitian yang dilakukan oleh Tang dan Chang (2010), tetapi pada penelitian lain hasilnya adalah ambiguitas peran memiliki pengaruh positif yag signifikan dan konflik peran mempengaruhi tetapi tidak signifikan pada kreativitas karyawan, ini disebabkan oleh perbedaan jenis organisasi yang sedang diteliti.

\section{KESIMPULAN}

Hasil dari pembahasan dalam penelitan ini dapat di simpulkan bahwa alumni Fakultas Ekonomi dan Bisnis Universitas Lampung yang sudah bekerja dan berstatus karyawan harus menghindari ambiguitas peran untuk menghindari konflik terkait konflik peran dan organisasi harus mencari cara lain untuk merangsang dan meningkatkan kreativitas karyawan. Hal-hal seperti komunikasi memainkan peran besar dalam rangka memberikan arahan yang jelas, informasi tentang pekerjaan tertentu atau bahkan berkomunikasi tentang tujuan dan prosedur dalam organisasi. Manajer harus orang yang bertindak sebagai informator dan memberikan informasi kepada karyawan.

Kesimpulan lainnya bahwa ada pengaruh positif dan signifikan antara konflik peran dan kreativitas karyawa pada alumni Fakultas Ekonomi dan Bisnis Universitas Lampung yang sudah bekerja dan berstatus karyawan. Konflik peran bukan merupakan faktor yang sangat mempengaruhi, melainkan dipengaruhi oleh efikasi diri kepedulian yang memediasi hubungan antara konflik peran dan kreativitas yang tidak diteliti lebih lanjut dalam penelitian ini, meskipu ada pengaruh signifikan organisasi perlu menghindari konflik peran dengan memberi karyawan deskripsi pekerjaan yang jelas di seluruh divisi jadi mereka tidak harus melakukan tugas yang tidak kompatibel atau menyimpang dari deskripsi pekerjaan mereka saat ini untuk menghindari masalah yang muncul di masa depan.

Kesimpulan dan rekomendasi dari penelitian ini dapat disimpulkan bahwa: (1) Peran ambiguitas (X1) memiliki pengaruh positif dan signifikan terhadap kreativitas karyawan (Y) pada alumni Fakultas Ekonomi dan Bisnis Universitas Lampung status karyawan. (2) Konflik peran (X2) memiliki pengaruh positif dan signifikan terhadap kreativitas karyawan (Y) pada alumni Fakultas Ekonomi dan Bisnis Universitas Lampung status karyawan.

\section{PENUTUP}

Penelitian ini memiliki keterbatasan atau kekurangan yang perlu diperbaiki dalam penelitian-penelitian kedepannya, karena hakekatnya penelitian ini diharapkan dapat menjadi acuan dalam penelitian selanjutnya ataupun sebagai pendukung untuk penelitian lainnya. Keterbatasan atau kekurangan tersebut ialah, penelitian ini hanya terfokus untuk melihat bagaimana pengaruh ambiguitas peran dan konflik peran sebagai variabel $\mathrm{X}$ terhadap kreativitas karyawan sebagai variabel Y, tanpa membahas variabel lain diluar penelitian yang berpotensi untuk mempengaruhi kreativitas karyawan. Saran untuk peneliti selanjutnya adalah: (1) Uji selanjutnya diharapkan ada faktor-faktor lain yang dapat memengaruhi atau merangsang kreativitas karyawan. (2) Diharapkan untuk mengembangkan penelitian ini dengan menambahkan lebih banyak variabel yang mempengaruhi kreativitas karyawan. 


\section{REFERENSI}

Amabile TM (1983). The Social Psychology of Creativity. New York: Springer-Verlag.

Amabile TM (1988). A model of creativity and innovation in organization. In B. M. Staw and L. L. Cumming (Eds.), CT: JAI Press. Res. Org. Behav. pp. 123-126.

Amabile TM (1996). Creativity in Context. Boulder, Colorado, CO: Westview Press.

Amabile TM, Hill KG, Hennessey BA, Tighe EM (1994). The work preference inventory: Assessing intrinsic and extrinsic motivational orientations. J. Pers. Soc. Psychol., 66: 950-967.

Amabile TM, Conti R, Coon H, Lazenby J, Herron M (1996). Assessing the work environment for creativity. Acad. Manage. J., 39: 1154-1184.

Amabile TM, Gryskiewicz S (1987). Creativity in the $R \& D$ laboratory. Technical Report 30. Greensboro, NC: Center for Creative Leadership

Backer TE (1992). On work place creativity: Psychological, environmental, and organizational strategies. Creativity Res. J., 5: 439-441.

Baer M, Oldham GR (2006). The curvilinear relation between experienced creative time pressure and creativity: moderating effects of openness to experience and support for creativity. J. Appl. Psychol., 91(4): 963-970.

Beehr TA (1976). Perceived situational moderators of the relation between subjective role ambiguity and role strain. J. Appl. Psychol., 61: 35-40.

Beehr TA, Glazer S (2005). Organizational role stress. In Barling J. Kelloway E.K. and Frone M.R. (Eds.), Handbook of Work Stress. pp.7-33. Thousand Oaks, CA : Sage

Burnside RM (1990). Improving corporate climates for creativity. In M.A. West and J.L. Farr (Eds.), Chicherster, UK:Wiley. Innovations and Creativity at Work: Psychological and Organizational Strategies. pp. 265-284.

Farr JL, Ford CM (1990). Individual innovation. In innovation and creativity at work. In West M.A. and Farr J.L. (Eds.), New York: Wiley, Innovation and Creativity at Work. pp. $63-80$

George JM, Zhou J (2002). Understanding when bad moods foster creativity and good ones do not: The role of context and clarity of feelings. J. Appl. Psychol., 87: 687697.

Isen AM (1999a). On the relationship between affect and creative problem solving. In S.W. Russ (Ed.), Affect, Creative Experience and Psychological Adjustment. Philadelphia: Brunner/Mazel. pp. 3-18.

Isen AM (1999b). Positive affect. In T. Dagleish and M. Power (Eds.), New York: Wiley Handbook of Cognition and Emotion, pp. 521-539.. 
Janssen O (2000). Job demands, perceptions of effort-reward fairness and innovative work behavior. J. Occup. Organ. Psychol., 73: 287-302.

Jex SM (1998). Stress and Job Performance: Theory, Research, and Implications for Managerial Practice. Thousand Oaks, CA: Sage

Kahn RL, Wolfe DM, Quinn RP, Snoek JD, Rosenthal RA (1964). Organizational Stress: Studies in Role Conflict and Ambiguity. New York: Wiley.

Kalleberg A (2001). The advent of the flexible workplace: Implications for theory and research. In Cornfield D.,

Karadal H, Ay U, Cuhadar MT (2008). The effect of role conflict and role ambiguity on job satisfaction and organizational commitment: A study in the public and private sectors. J. Am. Acad. Bus., 13(2): 176-181

Rizzo JR, House RJ, Lirtzman SI (1970). Role conflict and ambiguity in complex organizations. Admin. Sci. Quart., 15: 150-163.

Zhou J, George JM (2001). When job dissatisfaction leads to creativity: Encouraging the expression of voice. Acad. Manage. J., 44: 682-696 